\title{
Synthesis and Characterization of Novel N-Benzylbenzimidazole Linked Pyrimidine Derivatives as Anticancer Agents
}

\author{
Gopal Krishna Padhy ${ }^{1,2}$, Jagadeesh Panda ${ }^{3}$, Ajaya Kumar Behera ${ }^{1, *}$ \\ ${ }^{1}$ Organic Synthesis Laboratory, School of Chemistry, Sambalpur University, Jyoti Vihar, Burla, Odisha, INDIA. \\ 'Department of Pharmaceutical Chemistry, Maharajah's College of Pharmacy, Phool Baugh, Vizianagaram, Andhra Pradesh, INDIA. \\ ${ }^{3}$ Department of Pharmaceutical Chemistry, Raghu College of Pharmacy, Dakamarri, Visakhapatnam, Andhra Pradesh, INDIA.
}

\begin{abstract}
Background: Emergence of resistance to accessible anticancer drugs became a threat to human lives in the recent time. To address this issue, discovery of novel anticancer agents becomes very essential. Benzimidazoles and pyrimidines have been reported to possess potent anticancer activity. Materials and Methods: A hybrid approach has been used, in which core structure of potentially active $\mathrm{N}$-benzyl benzimidazole and pyrimidine derivatives are brought together in to a single molecule. The desired compounds were prepared by the condensation of $\mathrm{N}$-benzyl benzimidazole chalcones with guanidine hydrochloride. The synthesized compounds were characterized using spectral studies (IR, ${ }^{1} \mathrm{H},{ }^{13} \mathrm{C}-\mathrm{NMR}$ techniques and mass spectrometry). All the compounds were screened for their anticancer activity against human breast cancer cell line MDA-MB-231. Results: The spectral data's are in well agreement with the synthesized compounds $5 a-e$. Compounds $5 \mathrm{~b}\left(\mathrm{Gl}_{50}=39.6 \mu \mathrm{M}\right)$ and $5 \mathrm{a}\left(\mathrm{GI}_{50}=84.0 \mu \mathrm{M}\right)$ exhibited significant anticancer activity. Conclusion: Owing to the anticancer activity, compound $5 \mathrm{~b}$ can be used as lead structure in the development of yet more potent anticancer agents.
\end{abstract}

Key words: Chalcone, Benzimidazole, Pyrimidine, Anticancer activity, SRB assay.

\section{INTRODUCTION}

In present situation cancer became a cruel reality to human lives due to their resistance to accessible drugs. Thus, discovery of new types of anticancer drugs becomes very critical. Benzimidazoles are exceptionally valuable for the development of anticancer agent as they inhibits several enzymes involved in pathology of cancer including tyrosine kinase, ${ }^{1}$ Raf kinase, ${ }^{2}$ phosphatidylinositol 3-kinase ${ }^{3}$ and insulin-like growth factor I receptor kinase. ${ }^{4}$ In addition, N-benzyl substituted benzimidazoles have been synthesized exhibiting potent anticancer activity in which the $\mathrm{PPTMB}^{5}$ and $\mathrm{BPB}^{6}$ are examples (Figure 1). The pyrimidine motif is a core structure in numerous biologically active compounds. Some representatives of this heterocycle exhibited anti- cancer activity. ${ }^{7-9}$ Moreover compounds like GNE- $477^{10}$ and certinib ${ }^{11}$ were reported as potential anticancer agents (Figure 1).

The hybrid of N-benzyl benzimidazole and pyrimidine moieties is anticipated to be a good approach to design promising anticancer agents. Thus in present work an efficient synthesis of some new N-benzyl benzimidazole linked pyrimidine derivatives were synthesized and evaluated against human breast cancer cell line MDA-MB-231.

\section{MATERIALS AND METHODS}

\section{Materials and Instrumentation}

The chemicals used were procured from Merck (India) and Finar (India). ${ }^{1} \mathrm{H}$ and ${ }^{13} \mathrm{C}$ NMR spectra were recorded on a Bruker
Submission Date: 11-09-2018; Revision Date: 08-01-2019; Accepted Date: 20-03-2019

DOI: 10.5530/ijper.53.2s.57 Correspondence: Dr. Ajaya Kumar Behera Organic Synthesis Laboratory, School of Chemistry, Sambalpur University, Jyoti Vihar, Burla 768019, Odisha, INDIA.

Phone: +91-663-2430114 E-mail: ajay.behera1962@ gmail.com

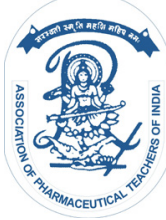

www.ijper.org 
Avance III $500 \mathrm{MHz}$ (AV 500), spectrometer using TMS as internal standard. The mass spectra were recorded on Varian Inc 410 prostar Binary LC-MS. IR spectra were obtained on a Bruker Alpha-T FT-IR spectrometer. Melting points were determined by open tube capillary method and are uncorrected. Progress of the reaction and purity of the products was checked by TLC under iodine vapors/UV light.

\section{General Method for the Synthesis of 4-(1-benzyl- 1H-benzo[d]imidazol-2-yl)-6-(Substituted Phenyl) Pyrimidin-2-amine (5a-e)}

Appropriate N-benzyl benzimidazole chalcone 4a-e ( $2 \mathrm{mmol}$ ) was dissolved in mixture of absolute alcohol $(10 \mathrm{ml})$ and aqueous sodium hydroxide solution $(10 \%$, $1 \mathrm{ml})$. Guanidine hydrochloride $(4 \mathrm{mmol})$ was added to the reaction mixture and the contents were refluxed until completion of reaction (10-12 h). The progress of the reaction was monitored by TLC (Benzene-ethyl acetate, 4:1). The reaction mixture was cooled and the precipitate formed was filtered and washed with rectified spirit.

\section{4-(1-benzyl-1H-benzo[d]imidazol-2-yl)-6- phenylpyrimidin-2-amine (5a)}

Yield: $72 \%$; cream colour solid; m.p. 204-206 ${ }^{\circ} \mathrm{C}$; FTIR $(\mathrm{KBr}) \mathrm{cm}^{-1} 3404\left(\mathrm{br},-\mathrm{NH}_{2}\right), 1628(\mathrm{C}=\mathrm{N}) ;{ }^{1} \mathrm{H}-\mathrm{NMR}(500$ $\mathrm{MHz}_{\mathrm{z}}$ DMSO-d $\left.\mathrm{d}_{6} \delta / \mathrm{ppm}\right): 8.15-8.13\left(2 \mathrm{H}, \mathrm{m}, \mathrm{H}-2^{\prime}\right.$ and H-6'), 7.97 (1H, s, H-15), 7.80 (1H, d, J = 7 Hz, H-4) $7.71(1 \mathrm{H}, \mathrm{d}, J=7.5 \mathrm{~Hz}, \mathrm{H}-7), 7.54-7.53$ ( $3 \mathrm{H}, \mathrm{m}, \mathrm{H}-3$, H-5 and H-4 ), 7.35-7.29 (2H, m, H-5 and H-6), 7.267.23 (2H, m, H-3" and H-5"), 7.20-7.16 (3H, m, H-2", H-6" and H-4"), $7.02\left(2 \mathrm{H}, \mathrm{s},-\mathrm{NH}_{2}\right), 6.37(2 \mathrm{H}, \mathrm{s}, \mathrm{H}-10)$; ${ }^{13} \mathrm{C}$ NMR (125 MHz, DMSO-d $): 165.49$ (C12), 163.86 (C16), 159.18 (C14), 148.21 (C2), 142.52 (C8), 138.46 (C1"), 137.30 (C1'), 137.23 (C9), 131.22 (C4'), 129.28 (C3' and $\left.\mathrm{C5}^{\prime}\right), 128.98$ (C3 " and $\left.\mathrm{C5}^{\prime \prime}\right), 127.74\left(\mathrm{C} 4^{\prime \prime}\right)$, 127.44 (C2" and $\left.\mathrm{C6}^{\prime \prime}\right), 127.28$ (C2' and $\left.\mathrm{C6}^{\prime}\right), 124.48$ (C6), 123.33 (C5), 120.41 (C4), 112.04 (C7), 104.90 (C15), 48.42 (C10); ESI-MS m/z: 378.1 [M+H]..

\section{4-(1-benzyl-1H-benzo[d]imidazol-2-yl)-6-(p-tolyl) pyrimidin-2-amine (5b)}

Yield: $62 \%$; cream colour solid; m.p. $180-182^{\circ} \mathrm{C}$; FTIR $(\mathrm{KBr}) \mathrm{cm}^{-1} 3306\left(-\mathrm{NH}_{2}\right), 1624(\mathrm{C}=\mathrm{N}) ;{ }^{1} \mathrm{H}-\mathrm{NMR}(500$, MHz, DMSO-d $\left.{ }_{6}, \delta / \mathrm{ppm}\right): 8.05\left(2 \mathrm{H}, \mathrm{d}, J=10 \mathrm{~Hz}, \mathrm{H}-2^{\prime}\right.$ and $\left.\mathrm{H}_{-6}^{\prime}\right), 7.94(1 \mathrm{H}, \mathrm{s}, \mathrm{H}-15), 7.79(1 \mathrm{H}, \mathrm{dd}, \mathrm{J}=5 \mathrm{~Hz}, J$ $=10 \mathrm{~Hz}, \mathrm{H}-4), 7.70(1 \mathrm{H}, \mathrm{dd}, J=5 \mathrm{~Hz}, J=10 \mathrm{~Hz}, \mathrm{H}-7)$, 7.35-7.29 (4H, m, H-3', H-5', H-5 and H-6 ), 7.26-7.23 $\left(2 \mathrm{H}, \mathrm{m}, \mathrm{H}-3^{\prime \prime}\right.$ and $\left.\mathrm{H}-5^{\prime \prime}\right), 7.19-7.16\left(3 \mathrm{H}, \mathrm{m}, \mathrm{H}-2^{\prime \prime}, \mathrm{H}-6^{\prime \prime}\right.$ and $\left.\mathrm{H}-4^{\prime \prime}\right), 6.98\left(2 \mathrm{H}, \mathrm{s},-\mathrm{NH}_{2}\right), 6.37$ (2H, s, H-10), 2.38 $\left(3 \mathrm{H}, \mathrm{s},-\mathrm{CH}_{3}\right)$; ESI-MS m/z: $392.1[\mathrm{M}+\mathrm{H}]$.

\section{4-(1-benzyl-1H-benzo[d]imidazol-2-yl)-6-(4-} chlorophenyl)pyrimidin-2-amine (5c)

Yield: $66 \%$; cream colour solid; m.p. 186--188 ${ }^{\circ} \mathrm{C}$;

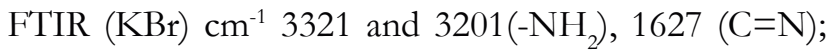
${ }^{1} \mathrm{H}-\mathrm{NMR}\left(500 \mathrm{MHz}, \mathrm{DMSO}-\mathrm{d}_{6}, \delta / \mathrm{ppm}\right): 8.18(2 \mathrm{H}, \mathrm{d}, J$ $=8.5 \mathrm{~Hz}, \mathrm{H}-2^{\prime}$ and $\left.\mathrm{H}-6^{\prime}\right), 7.98(1 \mathrm{H}, \mathrm{s}, \mathrm{H}-15), 7.80(1 \mathrm{H}$, $\mathrm{d}, J=7 \mathrm{~Hz}, \mathrm{H}-4) 7.77(1 \mathrm{H}, \mathrm{d}, J=7.5 \mathrm{~Hz}, \mathrm{H}-7), 7.6(2 \mathrm{H}$, $\mathrm{d}, J=9 \mathrm{~Hz}, \mathrm{H}-3^{\prime}$ and $\left.\mathrm{H}-5^{\prime}\right), 7.35-7.29(2 \mathrm{H}, \mathrm{m}, \mathrm{H}-5$ and $\mathrm{H}-6), 7.26-7.23$ (2H, m, H-3" and H-5"), 7.20-7.17 (3H, m, H-2", H-6" and H-4" ), $7.04\left(2 \mathrm{H}, \mathrm{s},-\mathrm{NH}_{2}\right), 6.37(2 \mathrm{H}$, s, H-10); ${ }^{13} \mathrm{C}$ NMR (125 MHz, DMSO-d $): 164.19$ (C12), 163.81 (C16), 159.37 (C14), 148.05 (C2), 142.49 (C8), 138.44 (C1'), 137.24 (C9), 136.09 (C4'), 136.00 (C1'), 129.35 (C2' and $\left.\mathrm{C6}^{\prime}\right), 129.10\left(\mathrm{C}^{\prime}{ }^{\prime}\right.$ and $\left.\mathrm{C}^{\prime}\right), 128.98\left(\mathrm{C3}^{\prime \prime}\right.$ and $\left.\mathrm{C5}^{\prime \prime}\right), 127.75$ (C4"), 127.43 (C2" and $\left.\mathrm{C6}^{\prime \prime}\right), 124.53$ (C6), 123.36 (C5), 120.41 (C4), 112.06 (C7), 104.74 (C15), 48.41 (C10); ESI-MS m/z: 411.9 [M+H].

\section{4-(1-benzyl-1H-benzo[d]imidazol-2-yl)-6-(4- bromophenyl)pyrimidin-2-amine (5d)}

Yield: $58 \%$; light yellow colour solid; m.p. $216-218^{\circ} \mathrm{C}$; FTIR $(\mathrm{KBr}) \mathrm{cm}^{-1} 3330$ and $3205\left(-\mathrm{NH}_{2}\right), 1627(\mathrm{C}=\mathrm{N})$; ${ }^{1} \mathrm{H}-\mathrm{NMR}(500 \mathrm{MHz}$, DMSO-d,$\delta / \mathrm{ppm}): 8.10(2 \mathrm{H}, \mathrm{d}$, $J=8.5 \mathrm{~Hz}, \mathrm{H}-2^{\prime}$ and $\left.\mathrm{H}^{\prime} \mathrm{6}^{\prime}\right), 7.97(1 \mathrm{H}, \mathrm{s}, \mathrm{H}-15), 7.80(1 \mathrm{H}$, $\mathrm{dd}, J=1.5 \mathrm{~Hz}, J=7.5 \mathrm{~Hz}, \mathrm{H}-4), 7.75-7.70\left(3 \mathrm{H}, \mathrm{m}, \mathrm{H}-3{ }^{\prime}\right.$, $\mathrm{H}-5^{\prime}$ and H-7), 7.36-7.29 (2H, m, H-5 and H-6), 7.267.23 (2H, m, H-3" and H-5"), 7.20-7.17 (3H, m, H-2", H-6" and $\left.\mathrm{H}-4^{\prime \prime}\right), 7.04\left(2 \mathrm{H}, \mathrm{s},-\mathrm{NH}_{2}\right), 6.36(2 \mathrm{H}, \mathrm{s}, \mathrm{H}-10)$; ESI-MS m/z: 455.9 [M+H], 457.9 [M+2].

\section{4-(1-benzyl-1H-benzo[d]imidazol-2-yl)-6-(4- fluorophenyl)pyrimidin-2-amine (5e)}

Yield: $68 \%$; cream colour solid; m.p. $210-212^{\circ} \mathrm{C}$; FTIR $(\mathrm{KBr}) \mathrm{cm}^{-1} 3373$ and $3294\left(-\mathrm{NH}_{2}\right), 1633(\mathrm{C}=\mathrm{N})$; ${ }^{1} \mathrm{H}-\mathrm{NMR}$ (500 MHz, DMSO-d,$\delta$ / ppm): 8.23-8.20 $\left(2 \mathrm{H}, \mathrm{m}, \mathrm{H}-2^{\prime}\right.$ and H-6'), 7.98 (1H, s, H-15), $7.81(1 \mathrm{H}, \mathrm{d}$, $J=7.5 \mathrm{~Hz}, \mathrm{H}-4), 7.71(1 \mathrm{H}, \mathrm{d}, J=8 \mathrm{~Hz}, \mathrm{H}-7), 7.36-7.29$ $\left(4 \mathrm{H}, \mathrm{m}, \mathrm{H}-5, \mathrm{H}-6, \mathrm{H}-3^{\prime}\right.$ and $\left.\mathrm{H}-5^{\prime}\right), 7.25-7.16(5 \mathrm{H}, \mathrm{m}$,

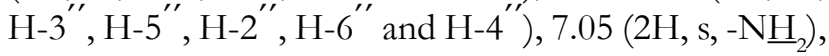
$6.38(2 \mathrm{H}, \mathrm{s}, \mathrm{H}-10) ;{ }^{13} \mathrm{C}$ NMR (125 MHz, DMSO-d $)$ : 165.23-163.26 (C4'), 164.37 (C12), 163.80 (C16), 159.25 (C14), 148.16 (C2), 142.52 (C8), 138.45 (C1"), 137.23 (C9), 133.77-133.75 (C2' and C6 ), 129.74-129.67 (C1'), 128.97 (C3" and $\left.\mathrm{C5}^{\prime \prime}\right), 127.74$ (C4"), 127.43 (C2" and C6"), 124.49 (C6), 123.34 (C5), 120.40 (C4), 116.27 (C3' and $\left.\mathrm{C} 5^{\prime}\right), 116.10\left(\mathrm{C5}^{\prime}\right), 112.03$ (C7), 104.69 (C15), 48.42 (C10); ESI-MS m/z: $396.1[\mathrm{M}+\mathrm{H}]$.

\section{Anticancer activity}

The in vitro cytotoxicity activities (cell viability assay) of the compounds were evaluated by SRB assay ${ }^{12}$ against Human breast cancer cell line MDA-MB-231. The cell 
line was grown in RPMI 1640 medium containing 2 $\mathrm{mM}$ L-glutamine and 10\% fetal bovine serum. Cells were inoculated into 96 well microtiter plates in $90 \mu \mathrm{L}$ medium at 5000 cells per well and incubated at $37^{\circ} \mathrm{C}$, $5 \% \mathrm{CO}_{2}, 95 \%$ air and $100 \%$ relative humidity for 24 h. Subsequent to the addition of drugs $(0.1-100 \mu \mathrm{M})$, the culture plate was incubated for additional $48 \mathrm{~h}$. Cells were fixed in situ by slowly adding $25 \mu \mathrm{L}$ of $10 \%$ trichloroacetic acid and then incubated for $60 \mathrm{~min}$ at $4{ }^{\circ} \mathrm{C}$. After discarding the supernatant, the plate was washed five times with tap water. Finally, $50 \mu \mathrm{L}$ of sulforhodamine in $1 \%$ acetic acid solution was added to each well for staining. The stained cells were solubilized using $10 \mathrm{mM}$ trizma base and the absorbance was noted at a wavelength of $515 \mathrm{~nm}$. The \% viability was calculated for each compound at different concentration using the formula: (Absorbance of Test/Absorbance of control) $\times 100$

The $\mathrm{GI}_{50}$ (Concentration required to cause $50 \%$ inhibition in growth) for the synthesized compounds were calculated from a non-linear sigmoidal dose-response (Variable slope) curve by using GraphPad Prism v.4.03 software.

\section{RESULTS AND DISCUSSION}

\section{Synthesis}

The desired compounds were prepared as outlined in the (Scheme 1). 2-hydroxyethylbenzimidazole 1 was obtained by condensation of $o$-phenylenediamine with lactic acid under acidic condition. Oxidation of the 1 followed by neutralization with ammonia gave 2 -acetylbenzimidazole $2 .^{13}$ The required chalcones 3a-e were obtained by claisen-schmidt condensation of 2-acetylbenzimidazole 2 with substituted aromatic aldehydes in presence of $\mathrm{NaOH} .{ }^{14} \mathrm{~N}$-Benzyl substituted benzimidazole chalocones (4a-e) were obtained by nucleophilic substitution reactions of ${ }^{1} \mathrm{H}$-Benzimidazole chalcones (3a-e) with benzyl chloride. ${ }^{15}$ Condensation of the N-benzyl benzimidazole chalcones with guanidine

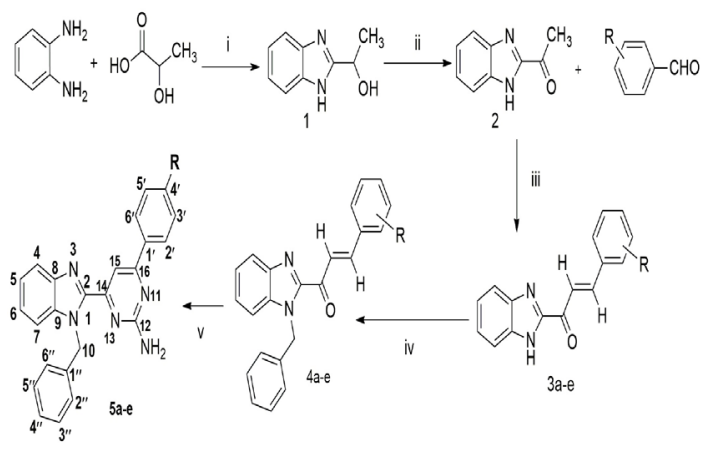

compound 5a; R=H 5b; R=CH $5 c ; \mathrm{R}=\mathrm{Cl} 5 \mathrm{~d} ; \mathrm{R}=\mathrm{Br}$ 5e; R=F hydrochloride resulted in novel pyrimidine derivatives (5a-e).

The scheme of synthesis 1: Synthetic route to 1-benzyl2-(1-substituted-5-aryl-4,5-dihydro-1H-pyrazol-3-yl)1H-benzo[d]imidazoles. Reagents and conditions: i) $4 \mathrm{~N}$ $\mathrm{HCl}$, reflux, 8 h; ii) $\mathrm{K}_{2} \mathrm{Cr}_{2} \mathrm{O}_{7}$, dil. $\mathrm{H}_{2} \mathrm{SO}_{4}$, r.t., 2h; iii) Ar$\mathrm{CHO}, 10 \%$ aq $\mathrm{NaOH}$, ethanol, r.t., 4-8 h; iv) Benzyl chloride, anhydrous $\mathrm{K}_{2} \mathrm{CO}_{3}$, dry acetone, reflux, 22-26 h; v) Guanidine. $\mathrm{HCl}, \mathrm{NaOH}, \mathrm{EtOH}, \mathrm{H}_{2} \mathrm{O}$, reflux, 10-12 h.

\section{Spectral Study}

The structures of synthesized compounds $5 \mathrm{a}-\mathrm{e}$ were assigned via spectroscopic analysis: IR, ${ }^{1} \mathrm{H}-\mathrm{NMR},{ }^{13} \mathrm{C}$ NMR and mass spectrometry. The spectral study of compound $5 \mathrm{a}$ is described as an example. IR spectrum of compound $5 \mathrm{a}$ showed the characteristic peak at $3404 \mathrm{~cm}^{-1}$ corresponding to $\mathrm{N}-\mathrm{H}$ stretching. In ${ }^{1} \mathrm{HMR}$ spectrum of $5 \mathrm{a}$, the doublets due to arylidene protons disappeared, instead a singlet at $\delta 7.97$ is observed due to proton at $\mathrm{C} 15$ ensuring the formation of pyrimidine ring. The phenyl protons $\mathrm{H}-2^{\prime}$ and $\mathrm{H}_{-} \mathrm{G}^{\prime}$ appeared as a multiplet at $\delta 8.15-8.13$. The benzimidazole protons (H-4 and H-7) appeared as two separate doublets at $\delta$ 7.80 and $7.71(J=7.5 \mathrm{~Hz})$ respectively. One multiplet at $\delta$ 7.54-7.53 was attributed to three aromatic protons of phenyl group (H-3', H-5 and $\left.\mathrm{H}-4^{\prime}\right)$. Two benzimidazole protons ( $\mathrm{H}-5$ and $\mathrm{H}-6)$ were observed as a multiplet at $\delta$ 7.35-7.29. Two separate multiples at $\delta$ 7.26-7.23 and $\delta$ 7.20-7.16 were assigned to aromatic benzyl protons (H-3", H-5", H-2", H-6" and H-4" ). The amino protons appeared as a singlet at $\delta$ 7.02. The methylene protons at $\mathrm{C} 10$ appeared as a singlet at $\delta 6.37$.

The ${ }^{13} \mathrm{C}$ NMR spectrum of compound $5 \mathrm{a}$, the peaks at $\delta$ $165.49,163.86,159.18,104.90$ are attributed to pyrimidine carbons (C12, C16, C14 and C15). The peaks at $\delta 148.21,142.52,137.23,124.48,123.33,120.41$ and 112.04 are assigned to benzimidazole carbons (C2, C8, C9, C6, C5, C4 and C7). The aromatic benzyl carbons (C1"), (C3" and $\left.\mathrm{C}^{\prime \prime}\right),\left(\mathrm{C} 2^{\prime \prime}\right.$ and $\left.\mathrm{C6}{ }^{\prime \prime}\right)$ and (C4") appeared at $\delta 138.46,128.98,127.44$ and 127.74 respectively. The peaks at $\delta 131.22,137.30,127.28$ and 129.28 are assigned to $\left(\mathrm{C}^{\prime}\right),\left(\mathrm{C} 1^{\prime}\right),\left(\mathrm{C} 2^{\prime}\right.$ and $\left.\mathrm{C} 6^{\prime}\right)$ and $\left(\mathrm{C} 3^{\prime}\right.$ and $\mathrm{C}^{\prime}$ ) respectively. A peak at 48.42 confirms the presence of methylene carbon (C10). Additionally, ESI-MS spectrum showed a peak at $378.1(\mathrm{M}+\mathrm{H})$. Hence, the above spectral data are compatible with the structure of desired product $5 \mathrm{a}$.

\section{Anticancer Activity}

The in vitro anticancer activities (cell viability assay) of compounds were evaluated by SRB assay against Human breast cancer cell line MDA-MB-231. Compounds 5a 


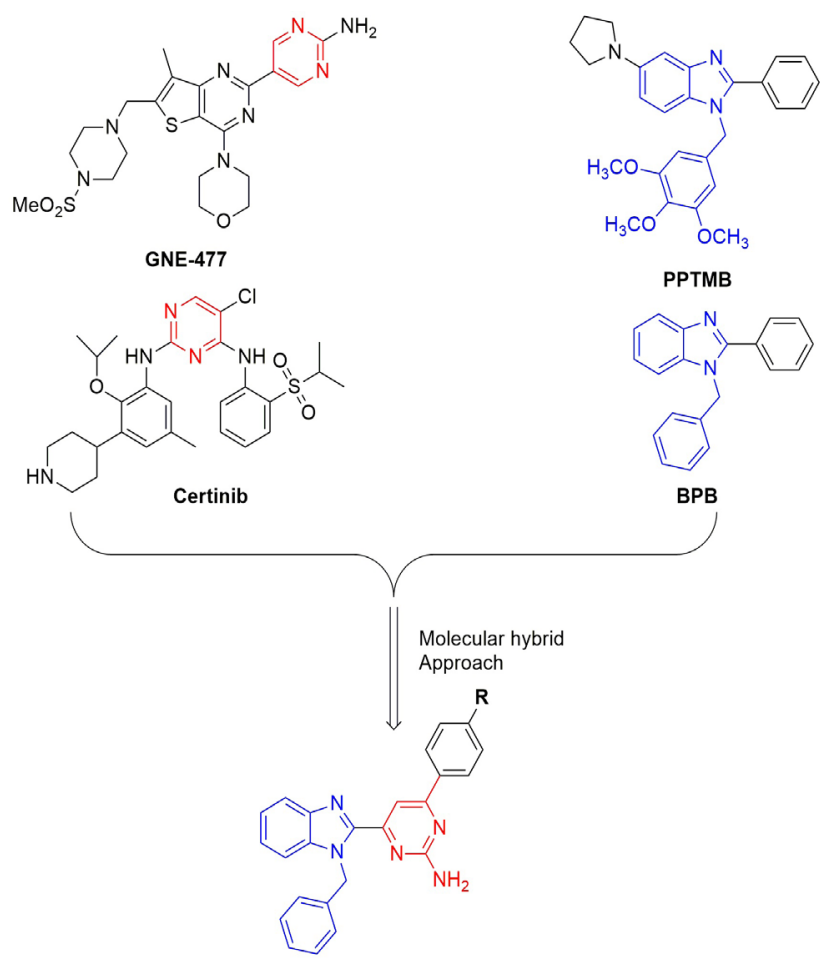

Figure 1: Rational Design of the Benzimidazole Linked Pyrimidine via Hybriding Potent Anticancer Agents.
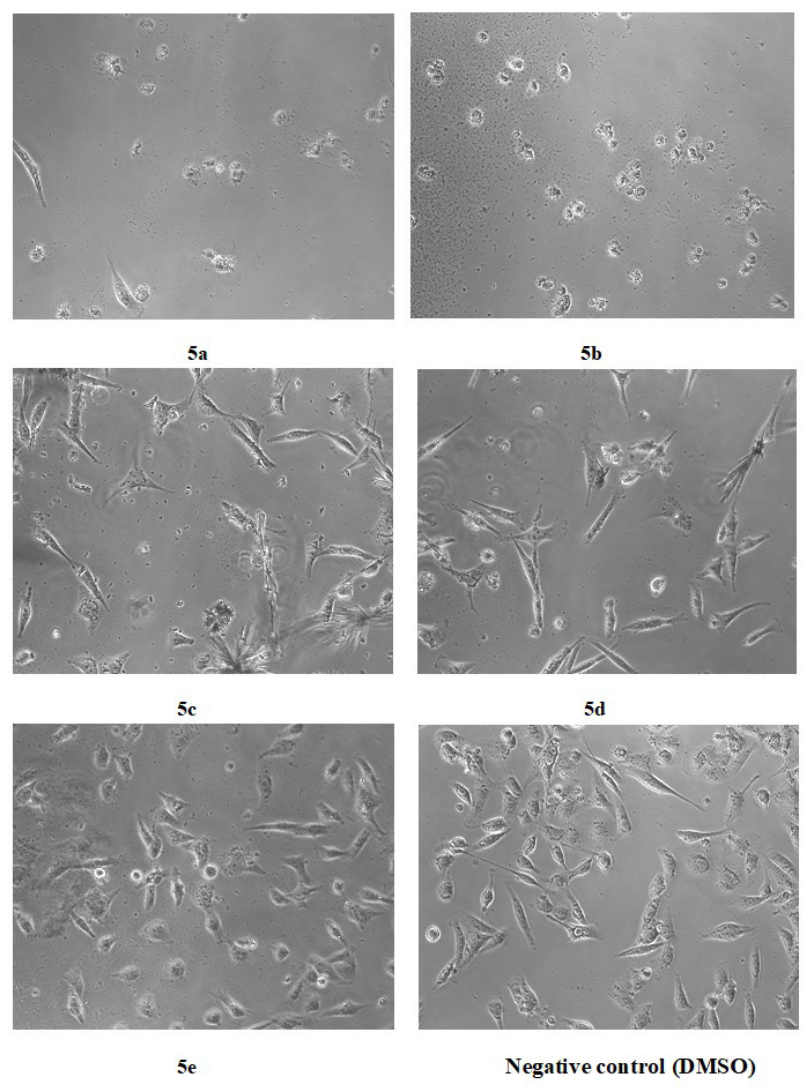

Figure 2: Images of Phase Contrast Microscopy. Cells were treated with $100 \mu \mathrm{M}$ 5a-e, for $48 \mathrm{~h}$. Negative Control Included cells treated with DMSO.
Table 1: In vitro anticancer activity of synthesized compounds $5 \mathrm{a}-\mathrm{e}\left(\mathrm{G} \mathrm{I}^{50} \mu \mathrm{M}\right)$.

\begin{tabular}{|c|c|}
\hline Compound & $\mathbf{G I}_{\mathbf{5 0}}(\boldsymbol{\mu M})$ \\
\hline $\mathbf{5 a}$ & 84.0 \\
\hline $\mathbf{5 b}$ & 39.6 \\
\hline $\mathbf{5 c}$ & $>100$ \\
\hline $\mathbf{5 d}$ & $>100$ \\
\hline $\mathbf{5 e}$ & $>100$ \\
\hline
\end{tabular}

Positive control Adriamycin $\left(\mathrm{Gl}_{50}=0.04 \mu \mathrm{M}\right)$.

$\left(\mathrm{GI}_{50}=84.0 \mu \mathrm{M}\right)$ and $5 \mathrm{~b}\left(\mathrm{GI}_{50}=39.6 \mu \mathrm{M}\right)$ exhibited weak activity. Compound $5 \mathrm{a}-\mathrm{b}$ clearly inhibited the proliferation of Human breast cancer cell line MDAMB-23 as shown in (Figure 2). All the other compounds found inactive $\left(\mathrm{GI}_{50}>100 \mu \mathrm{M}\right)$ as compared to standard drug adriamycin. The results obtained from cytotoxicity testing are represented in (Table 1).

\section{CONCLUSION}

Five novel benzimidazole derivatives containing pyrimidine ring were synthesized. The structures of new compounds were confirmed by spectral data (IR, ${ }^{1} \mathrm{H}-\mathrm{NMR}$, ${ }^{13} \mathrm{C}$-NMR and mass spectrometry). Our anticancer study results revealed that the most active compound $\mathbf{5 b}$ possessed $\mathrm{GI}_{50}$ value of $39.6 \mu \mathrm{M}$. Based on the $\mathrm{GI}_{50}$ values presented by the tested compounds, it could be concluded that, presence of electron releasing group on the phenyl ring enhanced the active.

\section{ACKNOWLEDGEMENT}

The authors gratefully acknowledge the Sophisticated Instrumentation Facility (SAIF), IIT Madras and SAIF, IIT Bombay for providing spectral data. The authors also acknowledge Anti-cancer drug screening facility (ACDSF) at ACTREC, Tata Memorial Centre, Navi Mumbai for evaluating anti-cancer activity. Gopal is thankful to Sri. P. Ashok Gajapathi Raju, Chairman, MANSAS, Vizianagaram and Dr. P. Udaya Shankar, Principal Maharajah's College of pharmacy, Vizianagaram for providing necessary infrastructure and facility.

\section{CONFLICT OF INTEREST}

The authors declare no conflict of interest.

\section{ABBREVIATIONS}

NMR: Nuclear magnetic resonance spectroscopy; TMS: Tetramethylsilane; DMSO-d $\mathbf{d}_{6}$ : Deuterated Dimethyl Sulfoxide; LC-MS: Liquid Chromatography- 
Mass spectrometry; ESI-MS: Electro spray ionizationMass Spectrometer; FT-IR: Fourier transform infrared spectroscopy; TLC: Thin layer chromatography; UV: Ultraviolet spectroscopy; SRB: Sulforhodamine B; RPMI: Roswell Park Memorial Institute.

\section{REFERENCES}

1. Hasegawa M, Nishigaki N, Washio $\mathrm{Y}$, Kano $\mathrm{K}$, Harris $\mathrm{PA}$, Sato $\mathrm{H}$, et al. Discovery of novel benzimidazoles as potent inhibitors of TIE-2 and VEGFR-2 tyrosine kinase receptors. J Med Chem. 2007;50(18):4453-70.

2. Ramurthy S, Subramanian S, Aikawa M, Amiri P, Costales A, Dove J, et al. Design and synthesis of orally bioavailable benzimidazoles as Raf kinase inhibitors. J Med Chem. 2008;51(22):7049-52.

3. Yaguchi S, Fukui Y, Koshimizu I, Yoshimi H, Matsuno T, Gouda H, et al. Antitumor activity of ZSTK474, a new phosphatidylinositol 3-kinase inhibitor. J Natl Cancer Inst. 2006;98(8):545-56.

4. Wittman M, Carboni J, Attar R, Balasubramanian B, Balimane P, Brassil P, et al. Discovery of a 1H-Benzoimidazol-2-yl)-1H-pyridin-2-one (BMS-536924) inhibitor of insulin-like growth factor I receptor kinase with in vivo antitumor activity. J Med Chem. 2005;48(18):5639-43.

5. Chang WL, Chang CS, Chiang PC, Ho YF, Liu JF, Chang KW, et al. 2-Phenyl-5-(pyrrolidin-1-yl)-1-(3, 4, 5-trimethoxybenzyl)-1H-benzimidazole, a benzimidazole Derivative, Inhibits growth of human prostate cancer cells by affecting tubulin and c-Jun N-terminal kinase. $\mathrm{Br} J$ Pharmacol. 2010;160(7):1677-89.

6. Liu JF, Huang YL, Yang WH, Chang CS, Tang CH. 1-Benzyl-2phenylbenzimidazole (BPB), a benzimidazole derivative, induces cell apoptosis in human chondrosarcoma through intrinsic and extrinsic pathways. Int J Mol Sci. 2012;13(12):16472-88.
7. Ma LY, Pang LP, Wang B, Zhang M, Hu B, Xue DQ, et al. Design and synthesis of novel 1, 2, 3-triazole-pyrimidine hybrids as potential anticancer agents. Eur J Med Chem. 2014;86:368-80.

8. El-Deeb IM, Lee SH. Design and synthesis of new anticancer pyrimidines with multiple kinase inhibitory effect. Bioorg Med Chem. 2010;18(11):386074.

9. Wang S, Griffiths G, Midgley CA, Barnett AL, Cooper M, Grabarek $\mathrm{J}$, et al. Discovery and Characterization of 2-Anilino-4-(thiazol-5-yl) pyrimidine transcriptional CDK inhibitors as anticancer agents. Chem Boil. 2010;17(10);1111-21.

10. Heffron TP, Berry M, Castanedo G, Chang C, Chuckowree I, Dotson J, et al. Identification of GNE-477, a potent and efficacious dual PI3K/mTOR inhibitor. Bioorg Med Chem Lett. 2010;20(8):2408-11.

11. Crinò L, Ahn MJ, De-Marinis F, Groen HJ, Wakelee H, Hida T, et al. Multicenter phase II study of whole body and intracranial activity with ceritinib in patients with ALK-rearranged non-small-cell lung cancer previously treated with chemotherapy and crizotinib: results from ASCEND-2. J Clin Oncol. 2016;34(24):2866-73.

12. Vichai V, Kirtikara K. Sulforhodamine B colorimetric assay for cytotoxicity screening. Nat Protoc. 2006;1(3):1112-6.

13. Reddy VM, Reddy KR. Synthesis and antibacterial activity of some novel 6-(1H-Benz [d] imidazol-2-yl)-8-(5-nitro-2-furyl)-3-(4-pyridyl)-7, 8-dihydro $[1,2,4]$ triazolo $[3,4-b][1,3,4]$ thiadiazepines. Chem Pharm Bull. 2010;58(8):1081-4.

14. Ouattara M, Sissouma D, Koné MW, Menan HE, Touré SA, Ouattara L. Synthesis and anthelmintic activity of some hybrid benzimidazolyl-chalcone derivatives. Trop J Pharm Res. 2011;10(6):767-75.

15. Padhy GK, Panda J, Behera AK. Synthesis and characterization of novel benzimidazole embedded 1, 3, 5-Trisubstituted pyrazolines as antimicrobial agents. J Serb Chem Soc. 2017;82(9):985-93.

\section{PICTORIAL ABSTRACT}

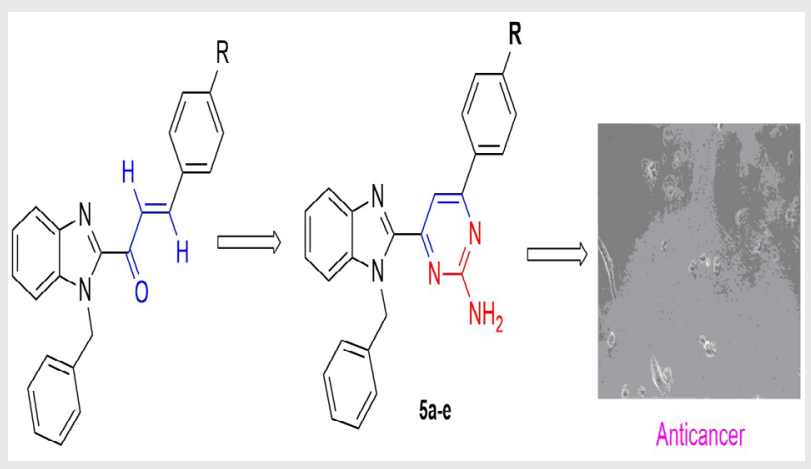

\section{SUMMARY}

- Identification of lead molecules against cancer is a vital area of today's research. In this study a new series of N-benzyl benzimidazole and pyrimidine derivatives were synthesized, characterized and evaluated for in vitro anticancer activity. Compound $5 \mathrm{~b}$ showed significant activity. Hence it can be used as a lead structure in the advance of yet more potent anticancer agents.

\section{ABOUT AUTHORS}

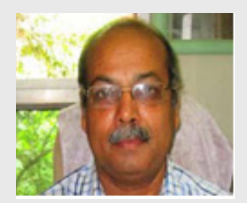

Dr. Ajaya Kumar Behera was born in Nayagarh District of Odisha, India, in 1962. He received his M.Sc. degree from Utkal University in 1984 and M.Phil. and Ph.D. degrees from Berhampur University in 1990 and 1996, respectively. After working for a few years at Government College, he joined the PG Department of Chemistry, Sambalpur University, in 1997 as Senior Lecturer and became Reader in 2003. His research interest includes synthesis of pharamacologically active heterocycles, spiroheterocycles and natural products.

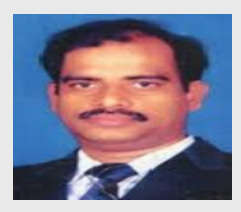

Dr. Jagadeesh Panda received his M.Pharm. degree from Andhra University in 1995 and Ph.D. degrees from Berhampur University in 2004 respectively. Currently he is working as a Professor and Principal of Raghu College of Pharmacy, Visakhapatnam. His research interest includes synthesis of pharamacologically active heterocycles and natural products. 
Dr. Gopal Krishna Padhy obtained his M.Pharm. degree in Pharmaceutical Chemistry from Poona College of Pharmacy, Bharati Vidyapeeth University, in 2007. He had carried out his Ph.D. work under joint supervision of Dr. Ajaya Kumar Behera and Dr. Jagadeesh Panda in Sambalpur University. Currently, he is working as an associate professor in Maharajah's College of Pharmacy, Phool Baugh.

Cite this article: Padhy GK, Panda J, Behera AK. Synthesis and Characterization of Novel N-Benzylbenzimidazole Linked Pyrimidine Derivatives as Anticancer Agents. Indian J of Pharmaceutical Education and Research. 2019;53(2S):s129-s134. 